\title{
A STRUCTURAL MODEL OF BUSINESS PERFORMANCE: An Empirical Study on Tobacco Farmers
}

\author{
Sony Heru Privanto
}

Fewstudies havebeen conducted on how farmers' entrepreneurship affects their farm performance. However, factors of entrepreneurship have not been adequately explored by researchers. Textbooks and articles on farm management usually stress the importance of farmers' management capability with respect to their farm output. Unfortunately, they have failed to relate management capability to entrepreneurship.

This study was conducted using a multilevel analysis with Structural Equation Model (SEM) to know the causal relationships among environment factors such as the country's economy, natural resources, institutions and organizations, individual backgrounds, entrepreneurship, managementcapacity, and farm performance. The cross-sectional data was obtained in 2003 from four dominant tobacco-producing districts in Central Java. The multilevel model that relates external environment, entrepreneurship, and management capacity-can adequately represent the data to estimate farm performance.

The results of the analysis indicate that factors like personal aspects, together with physical, economic and institutional environments, affectfarmers' entrepreneurship. Personal aspects turn out to be the dominant factor that determines entrepreneurship and farm performance. This study also shows that farmers' entrepreneurship is affected by their management capacity, which, in turn, affects the farmers'farm performance.

While there is no doubt in the adequacy of the model to estimate farm performance, this finding invites further investigation to validate 
Gadjah Mada International Journal of Business, January-April 2006, Vol.8, No. 1

it in other fields and scale of business, such as in small and medium enterprises and other companies. Furthermore, in order to evaluate the goodness of fit of the model in various contexts, further research both in a cross-cultural context and cross-national contexts using this model should be conducted.

Keywords: economic and institutional environment; entrepreneurship; farm performance; management capacity; multilevel analysis; personal aspect; physical; structural equation model

\section{Introduction}

Globalization, as a strategy for survival, competition and growth, is drawing more and more attention these days. Due to many factors such as the national market limitation, different nations' diverse and unequal resource endowments, technological development complexity, different levels of development and demand patterns, various production costs and efficiencies, and the technological revolution in various fields such as communication, globalization has become mandatory (Mittal 2003).

In the face of globalization, the Government has become more aware that rather than doing business, it should focus on creating a favorable environment in which business thrives and entrepreneurial instincts are aroused so that the investors may get the most out of their investments. With radical liberalization being introduced, the world economy becomes progressively market oriented and integrated with the emerging global economic structure in a more meaningful way (Mittal 2003).
With respect to food companies, Grunert et al. (1996) argue that their competitiveness is the result of several tendencies acting on and reinforcing one another. These tendencies are as follows: (1) in prosperous economies, growth in the food product market is measured in terms of value, rather than quantity, (2) there is an oversupply of agriculture product in most industrialized country, (3) the worldwide tendency towards deregulation, the decrease in government subsidies for the food and agriculture industry, and the reduction of trade barriers have made food companies vulnerable to competition, (4) with consumer demand becoming more fragmented and less consistent, consumer behavior is becoming less predictable, and (5) powerful agents, the products of the increasing concentration in the retail sector, become the gatekeepers that put food manufacturers under pressure.

Some farmers, industries, and Western countries have tried to make some improvements, especially in the new product development in which the production processes are done through 
Research and Development (R\&D). They are trying to increase their competitive advantage using progressive means, such as investment innovation and agricultural product development. Based on the situation, in the future, producers need to become more market oriented.

Indonesia will become part of the free trade era. In this era, entrepreneurship, i.e., need of achievement, creativity, risk taking, entrepreneurial learning, skill will be needed to cope with the challenges globalization brings about (Idrus 2003). Cantillon (1755) acknowledged that entrepreneurship is the fourth factor of production but he was unable to see it as a major force in economic development. In Schumpeter's (1934) system, entrepreneurship is deemed to be a creative activity. "The entrepreneur is the innovative individual who introduces something new into the economy." The innovation can be a production method not yet tested in any of a manufacturer's divisions, a completely novel product unfamiliar to the consumers, a new source of raw materials or an unexploited new market, or other innovations in the narrow sense of the term (Mitta12003).

According to Schumpeter (1934), an entrepreneur is "the agent who provides economic leadership that changes the economic conditions of the economy and causes discontinuous dynamic changes, the driving force behind economic growth, formulating new economic combination by (1) developing new products, (2) developing new sources of materials, (3) accumulating capital resources, (4) introducing new products and new production functions, and (5) recognizing or developing a new industry."

Because of the importance of entrepreneurship to economic growth and because Indonesia is an agricultural country, it is important to study entrepreneurship in relation to farming as soon as possible.

Rougoor et al. (1998) stated that despite many books and articles on farm management and decision theories, the management process itself largely remains a black box, and management capacity is rarely explicitly defined and measured. Moreover, research and reviews on management are still focusing on technical aspects. Therefore, the managerial, social and psychological aspects in the decision making process have been largely ignored.

Wilson et al. (2001) stated that many studies identify great variation in the physical progress and financial conditions of the same economic situation. Kay and Edward (1994) argued that in many instances this difference in performance is due to variation in management. However, unlike land, labor and capital, management is not directly observable; therefore, making it more difficult to explain the influence of management on farm performance.

Rougoor et al. (1998) tried to elaborate on the previous empirical research on the correlation between variables of management and farm performance. They conclude manage- 
Gadjah Mada International Journal of Business, January-April 2006, Vol.8, No. 1

ment capacity influences farm production. The same research indicates that recent studies have frequently used the production frontier approach to estimate the technical and/or economic efficiency of the farm. Rougoor suggests doing a stepwise analysis, looking for the connection between personal aspects and the decision-making process which influences farm production.

Wilson et al. (2001) responded to their studies but do not do a stepwise analysis on the affected and affecting management variables. Therefore, this present research aims to reconstruct the conceptual framework of farm performance comprehensively, while taking into account external environment, entrepreneurship, and management capacity.

In addition, Baum et al. (2001), in their study, found, among others that venture growth is a complex process that is affected by numerous and various interconnected micro and macro domains. Unlike previous findings, Baum, et al. began to untangle the multifaceted process by which entrepreneurs affect competitive strategy and performance. Based on their findings, they offered an internal explanation of venture growth. For example, they proposed that strategic decisionmaking and strategic choice theories could be utilized to study the process by which entrepreneurs formulate and implement their strategies so that crosslevel effects could be integrated (See Table 1 for a summary of previous research).

The current study attempts to posit a multilevel model that take into account environmental factors, individual characteristics, entrepreneurship, and management capacity as the appropriate model to describe the performance venture of the farmer; the way external environment influences the farmers' entrepreneurship and management capacity; the presence and absence of influence of personal entrepreneurship on the farmers' management capacity, the kind of influence it has; and the presence and absence of entrepreneurship and management capacity influence on farm performance.

The main purpose of this research is to test whether the multilevel model using the environmental factors - such as physical environment, organization, economic, individual characteristics, entrepreneurship and management capacity is, indeed, the appropriate model to describe farm performance. In addition, this study would also like to find out what influence the external environment has on both the farmers' entrepreneurship and management capacity, what influence the farmers' entrepreneurship has on this management capacity, and what influence the entrepreneurship and management capacity has on the farm performance. 
Priyanto-AStructuralModelofBusinessPerformance

Table 1. Outline of Previous Research

\begin{tabular}{|c|c|}
\hline Researchers & Outline of the Previous Research for Subsequent Research \\
\hline Gallacher etal.(1994) & $\begin{array}{l}\text { Farm management associations function primarily as mecha- } \\
\text { nisms to monitor the performance of agents, but do not per se } \\
\text { create in the design and subsequent adoption of improved } \\
\text { production practices. Further research on the efficiency impact } \\
\text { of organization forms should also emphasize dynamics. }\end{array}$ \\
\hline
\end{tabular}

Rougoor etal.(1998) Frontier production functions are widelyused in recent literature to estimate the technical and economic efficiency of farms. However, in explaining differences in efficiency, most studies merely a biographical variable (e.g., level of education). Their study concludes that a next step would be to include aspects of the decision-making process. Longitudinal on-farm observations, which give possibilities for studying the dynamic aspects of decision-making, are suggested to further analyze the concept of management capacity.

Orser, B. J. et al. (2000) The concept of managerial capacity requires further refinement and testing. Future research might also attempt to identify significant events that demarcate expansion among firms that express a growth intention.

Baum etal.(2001) Opportunities to study the internal aspects of venture growth using strategic decision-making and strategic choice theories to integrate cross level effects by studying how entrepreneurs formulate and implement their strategies.

Lee and Tsang (2001) A more fruitful research direction appears to be studying the relationship between an entrepreneur's skills, experience, learning behavior and performance.

Nuthall P.L(2001) A farmers' managerial ability can be improved. Research is necessary to develop procedures to achieve this, to compare and contrast these to isolate the most appropriate for different situation, and to ascertain the extent and type of improvement possible.

Wilson etal.(2001) Future studies that seek to explain variation in technical efficiency should include further aspects of the managerial decision-making process. 
Gadjah Mada International Journal of Business, January-April2006, Vol.8, No. 1

\section{Theoretical Background}

\section{Relationship Between External Environment and Entrepreneurship.}

Beets (1990) stated that exogenous circumstances influence the agriculture system and farm production. In addition, Proshanskyet al. (1970), stated that physical environment influences individuals' attitude in their social life, including their venture. It has been shown that farmers' psychological aspects, such as extroversion, demographic and sociological aspects, influenced their entrepreneurship. In relation to extroversion, Lee and Tsang (2001) stated that having more networking, farmers will get more business information that will be beneficial to their business. Therefore, a successful entrepreneur needs not only to manage the internal operation of his firm, but also to establish an external network.

In addition, Hisrich and Peters (1992) stated that demographic aspects are made up of educational levels, age, and personal values. Highly educated people usually have a wide repertoire of knowledge, and they believe that they have different experiences from those who have never got high education, so the highly educated people can create their own or their environment resources. In many cases, the educational level really influences someone's repertoire of knowledge which can activate the venture innovation. An educational level appropriate to one's business sector is important to develop one's venture (Hisrich and
Peters 1992). However, the educational level is not always linear with someone's ability because it also depends on the learning process taking place when he or she gets his or her education.

Educational levels in a large manufacturing company have been shown to have a positive relationship with venture growth. Cooper and Dunkelberg (1987) and Thompson (1986) find that compare to the general population, in US and Canada had a significantly higher level of education. In a similar vein, Robinson and Sexton (1994) observe that entrepreneurs had a higher level of education than the waged and salaried employees. They further find a positive relationship between educational levels and earning from selfemployment (Lee and Tsang 2001).

Personal values such as motivation, ability and capability affect decision-making process (Rougoors et al. 1998). Nuthall (2001) stated that trait, intelligence and motivation are constructs of individual behavior. Willock (1997) noted psychological factors do play an important role in farm decisionmaking. The researchers also related personality factors to goals and attitudes and gave what they regard as the direction and strength of causation.

Sociological aspects constructed by childhood family environment such as parents' occupations and parents' activity are also factors that build entrepreneurship. Having a self-employed father strongly inspired the entrepreneur who learns early on the indepen- 
dent nature and flexibility of self-employment exemplified by the father. The overall parental relationship, whether entrepreneur or not, is perhaps the most important aspect of the childhood family environment in establishing the desirability of entrepreneur activity for the individual. Parents can support and encourage their children to be independent, strive for high achievement, and assume responsibility (Hisrich and Peters 1992).

Mazzarol et al. (1999) stated that economic factor, like capital availability, is supported by institutions (banks, local and central governments), and regulations (such as bank credit interest subsidy). Access to capital information is of particular importance. The assets availability will influence the intentionality and decision making in running their business.

Farmers' accessibility to the customer also increases their attitude in venture. They will dare to take risks and increase their product quality, because they have known the market and dominated it. Mazzarol et al. (1999), also showed that an entrepreneur who is the first to get information will be more successful than others who get the information later on from the third person.

Market structures also influence farmers' entrepreneurship. Drucker (1985) stated that demography structure of regency could increase the innovation and creativity of an entrepreneur to fulfill the needs of the people.

A fertile physical environment with access to the water source, open capi- tal access and economic information will motivate people who live in the environment to study the use of the resources which will, then, influence their abilities and capabilities. According to Watson and Scott (1998), resources and management factors, the employees' condition, and technology will influence someone's entrepreneurship.

Relationship between Entrepreneurship and Management Capacity.

Rougoor et al. (1998) stated that successful business figures or leaders not only dominate the business management aspect, but also have strong personal aspects, such as drive and motivation, capability, credibility and good biography.

Nuthall (2001) stated that decision makers are influenced by emotions and stress despite the best intensions. Bohm and Pfister (1996) showed that emotions can have a significant effect on rationality of decisions. Emotion has an important role. Matthew and Deary (1998) discussed about anxiety and decision and note impact of neuroticism on decisions. Eysenck and Keane (1990) similarly noted that depressed people operate differently when in this state.

Furthermore, McGregor et al. (1995) found that British farmers did experience considerable stress. Thus, personality, emotions and current anxiety level must influence decision rationally and processes, and must be appropriately allowed for. Glancey et al. (1998) proposed that entrepreneur's characteristics will influence the mana- 
Gadjah Mada International Journal of Business, January-April 2006, Vol.8, No. 1

gerial operation that will later influence the business performance.

Relationship Between Management Capacity and Business Performance. The objectives of maximizing annual profit and maintaining the environment are positively correlated with, and have the largest influence on technical efficiency of the wheat farmer in England. Moreover, information-seeking farmers who seek the information, have more years of managerial experience, and having large farm are also associated with higher levels of technical efficiency (Wilson et al. 2001).

According to Gallacher et al (1994), management, ownership, and monitoring have a significant impact on marketing efficiency either on technical or cost efficiency. Monitoring by others (for example, by association) can increase the marginal revenue.

The hypotheses can be formulated based on insights from existing literature. As visual recap, Figure 1 shows the constructs and their linkage in causal model of entrepreneurship dynamic.

\section{Research Design}

To acquire various business and economic environments of tobacco farmers in Central Java, district locations that differed greatly in agriculture, trade, industry and service sectors were selected. The determination of the location was based on the gross domestic product of each district as shown in Table 2. Only four districts were selected. These were Temanggung, Klaten, Kendal, and Grobogan.

The population of this research was tobacco farmers. The unit of analysis was the manager of the farm. Only respondents owning 0.5 or more acres of land were used in this study. Because the sampling frame was not available, using some criteria such as managerial positions, economic of scale, and management capacity, purposive/judgment

Table 2. Rationalization of Target Locations Based on the Sector Contribution to GDP

\begin{tabular}{|c|c|c|c|c|c|}
\hline \multirow[t]{2}{*}{ District/Sector } & \multicolumn{4}{|c|}{ Sector contribution for GDP (\%) } & \multirow{2}{*}{$\begin{array}{c}\text { Tobacco } \\
\text { Production } \\
\quad \text { (ton) }\end{array}$} \\
\hline & Agriculture & Trade & Industry & Service & \\
\hline Temanggung & 33.14 & 10.11 & 16.23 & 20.15 & $24,283.30$ \\
\hline Klaten & 18.49 & 27.00 & 27.00 & 12.21 & $1,698.00$ \\
\hline Kendal & 18.60 & 17.63 & 44.94 & 9.20 & $9,062.69$ \\
\hline Grobogan & 45.94 & 20.85 & 3.73 & 15.92 & $3,697.40$ \\
\hline
\end{tabular}

Sources: Statistic of Central Java 2002. 
Priyanto-AStructuralModelofBusiness Performance

Figure 1. Path Diagram of Relationship between Entrepreneurship, Management Capacity and Farm Performance

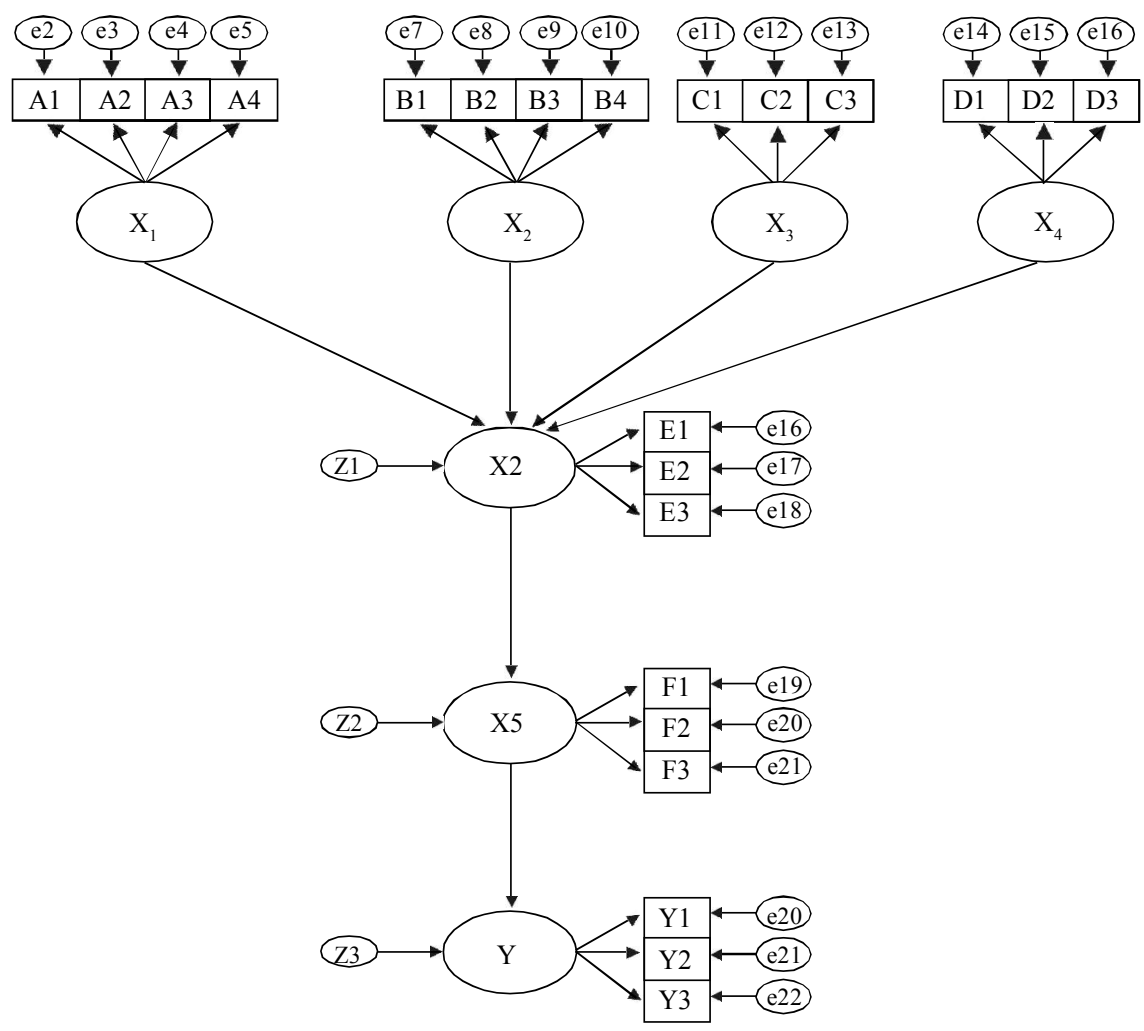

\footnotetext{
$\mathbf{X}_{1}=$ Economic Environment $\quad X_{3}=$ Organization Environ- $X_{6}=$ Management Capacity

A1 $=$ Price of input to output condition

A2 $=$ Capital Access

A3 $=$ Market Structure

A4 = Support from the Goverment and Tobacco Company

$X_{2}=$ Physical Environment

$\mathrm{B} 1=$ Meteorological condition

B2 = Soil Fertility

B3 = Technological Development

B4 = Infrastructure

$\mathrm{F} 1$ = Planning

$\mathrm{C} 1=$ Business Strategy $\quad$ F2 $=$ Implementing

C2 $=$ Business Culture $\quad$ F3 $=$ Controlling

$\mathrm{C} 3$ = Organization Structure

$\mathbf{Y}=$ Farm Performance

$\mathbf{X}_{4}=$ Individual Environment

$\mathrm{Y} 1=$ Productivity

Y2 $=$ Profit

$\mathrm{Y} 3=$ Price Level

D2 $=$ Sociological aspect

D3 = Biography

$\mathbf{X}_{5}=$ Entrepreneurship

$\mathrm{Zi}(\mathrm{Z1}, \mathrm{Z2}, \mathrm{Z3})=$ Error term related to the endogenous latent variable.

$\mathrm{E} 1=$ Knowledge

$\mathrm{E} 2$ = Attitude

$\mathrm{E} 3=$ Skill
} 
Gadjah Mada International Journal of Business, January-April 2006, Vol.8, No. 1

techniques were employed to select the sample. The total number of respondents participating in this study was 200 farmers; 50 respondents were chosen from each district. This number was adequate because it fulfilled the requirement of SEM (Structural Equation Model) analysis, i.e., at least 100 subjects for the analysis (Ferdinand 2002). Bentler and Chou (1987) indicate, for a structural equation model, that ratio between the sample size and the number of parameters to be estimated can go as low as five to one in the case of a normal distribution and ten to one in other cases. In this study, there were twenty three parameters to be estimated. Therefore, a minimum sample of 115 would be needed to attain the desired degree of precision, significant level, or goodness of fit (Thietart et al. 2001).

Data Analysis Techniques. According to the framework proposed earlier, this research will use an SEM analysis (Structural Equation Model) with the structural similarity below.

$\mathrm{x}_{5}=\gamma_{1} \mathrm{x}_{1}+\gamma_{2} \mathrm{x}_{2}+\gamma_{3} \mathrm{x}_{3}+\gamma_{4} \mathrm{x}_{4}+\zeta_{1}$

$\mathrm{x}_{6}=\alpha \mathrm{x}_{5}+\zeta_{2}$

$\mathrm{y}=\beta \mathrm{x}_{6}+\zeta_{3}$

$\gamma_{\mathrm{i}} \quad=$ Path of coefficient that shows the effect of the exogenous variable on the endogenous variable

$\alpha$ and $\beta=$ Path of coefficient that shows the effect of the endogenous variable on other endogenous variables. $\zeta_{\mathrm{i}}($ zeta $)=$ Error term related to the endogenous latent variable.

\section{Methodology}

\section{Research Procedures}

First, the district areas were determined. The locations were selected based on their economic structure as the GDP of each district and the number of tobacco production in the area, compared to other areas in Central Java.

Second, after selecting the districts, the municipalities where most farmers produced more than 0.5 acres were selected. Especially for Temanggung district, other than the farmer condition, the municipality selection was also based on the various soil fertility levels and characteristics. For Klaten district, the municipality selection criteria included the number of farmers planting tobacco for rajangan and asapan (sliced tobacco leaves and smoked tobacco leaves), the open market system, land renting and contract systems.

Third, after deciding on the locations, the next stage was selecting the farmers that planted more than 0.5 acres of tobacco. Then, with the help of village officials, heads of farmer groups and other key informants, sample respondents were selected there were 50 respondents in each district, thus, the total number of respondents was 200 . 


\section{Definition and Measure of the Variables}

The definition and variable measures investigated in the research are given below:

+ Farmperformance can bedescribed through three aspects, i.e. productivity, profit, and price.

+ Productivity can be measured by the output and input ratio or the number of output produced from the use of particular inputs such as land, capital, labor, time, etc (Beets 1990; Saudolet and Janvry 1995). In this research, productivity is measured by ton per acre.

+ Profit is measured by the average annual profit per acre.

+ Price is measured by the average price of one kilo of dry tobacco of lower, middle or upper quality. Performance is measured by the price because, in tobacco business, success is very much determined by the price of tobacco received by the farmers. Price proxies the quality of tobacco. The varied price is influenced by the amount and the quality of products in the market. Tobacco quality is divided into six levels: A, B, C, D, E, F, each with a different price. The A quality is the lowest and the $\mathrm{F}$ quality is the highest. Therefore, the quality of tobacco in the research is measured by the manifested variable tobacco price.

+ The decision making process performed by the farmers reflects their managerial ability (Nuthall 2001). This ability can be measured by their ability in planning, performing, and managing their business (Rougoors et al. 1998). A threepoint Likert-like scale was used to measure this variable.

+ Farmers' entrepreneurship was measured through their knowledge, attitude and skill. Knowledge is measured by the knowledge of agricultural technology, financial management, and marketing strategies. Attitude was measured by risk taking, independence and confidence, innovation and creation, and the need for achievement. Meanwhile, farmers' skill was measured by the new technology applied, the number of farm and business relations established, and the variation in marketing systems applied. A three-point Likertlike scale was used, where for each item, 1 indicated the lowest, 2 moderate and 3 the highest.

+ Individual characteristics were measured by (1) open personalities or not (extroversion); (2) sociological factors which involved parents' occupational backgrounds (measured by category or interval) and; (3) biography, as measured by age, education, and experience.

+ Organizational environment was measured by the business strategy, culture and organization management conditions. The attribute measure used a five-point Likert like scale.

+ Physical environment, the supporting structure and infrastructure that enables a business to run well, was measured by weather, humidity, in- 
Gadjah Mada International Journal of Business, January-April 2006, Vol.8, No. 1

frastructure, and the agriculture technology and information technology development, using a fivepoint Likert-like scale.

+ Economic environment, i.e., the economic condition affecting agriculture business, was accessed by the input and output price condition, capital access, market structure, access to suppliers and consumers, and government existing policies. Each attribute was measured by a five-point Likert-like scale.

Specifically for measuring the levels of farmers' entrepreneurship and management, scores 1, 2 and 3, were used, where 1 indicated the low level of entrepreneurship or management capacity, 2 the moderate level, and 3 the high level.

\section{Analyzes and Findings}

The proposed model according to the theory, was a structural model consisting of external environment, entrepreneurship, management capacity, and farm performance variables (see Figure 2). This proposed model fulfilled the criteria of goodness of fit when age, work experience, and growth of cultivation technology were excluded from the model. It was called competing model 1 (see Figure 3). The measurement of farm performance, i.e., productivity, became the production dimension; the support from the government and tobacco company variable became two dimensions: the govern- ment policy dimension and the tobacco company dimension. Meanwhile, the model connected all external environment latent variables with all management capacity latent variables. The model also connected the entrepreneurship latent variable with the farm performance latent variable.

Competing model 2 was the proposed model that had been modified by removing age, work experience, and cultivation technology growth from the model. Productivity became the production dimension, the support from the government and tobacco company variable became two dimensions: the government policy dimension and the tobacco company dimension. It meant that the model was the same as competing model 1, but its path diagram was similar to the proposed model (see Figure 4).

From the overall test results of competing model 2 (Table 4), whether through validity and reliability or overall test and measurements, the multilevel model consisting of physical environment, economical environment, organizational environment, individual characteristic, entrepreneurship, and management capacity could explain the phenomenon of farm performance. The measurement model had six concepts each with a composite reliability (CR) greater than 80 , four concepts with a CR between 70 and 79 , three with a CR between 60 and 69 , and ten concepts with a CR between 0.2 and 0.59 . All the concept-to-domain coefficients were statistically significant $(t>2.0, p<0.05)$; 
Priyanto-AStructuralModelofBusiness Performance

Figure 2. Path Analysis Result of Proposed Model

$$
\begin{aligned}
& \text { HYPOTHESIS TEST } \\
& \text { CHI-SQuARE }=971.791 \\
& \text { ProbaBILITY }=.000 \\
& \text { CMIN/DF }=3.599 \\
& \mathrm{GFI}=.740 \\
& \mathrm{TLI}=.636 \\
& \mathrm{CFI}=.673
\end{aligned}
$$

$\mathrm{RMSEA}=.115$

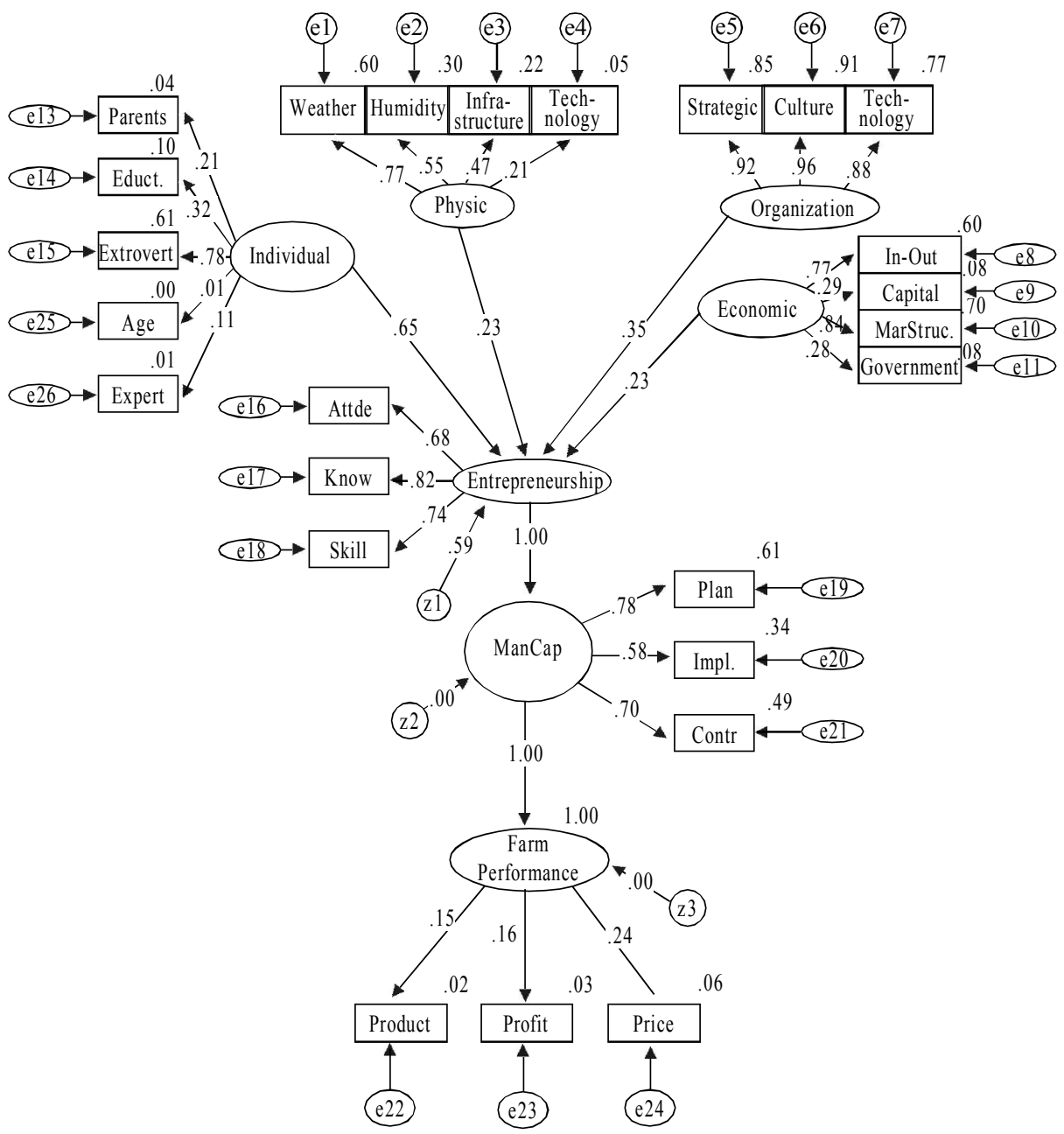


Figure 3. Path Analysis Result of Competing Model 1

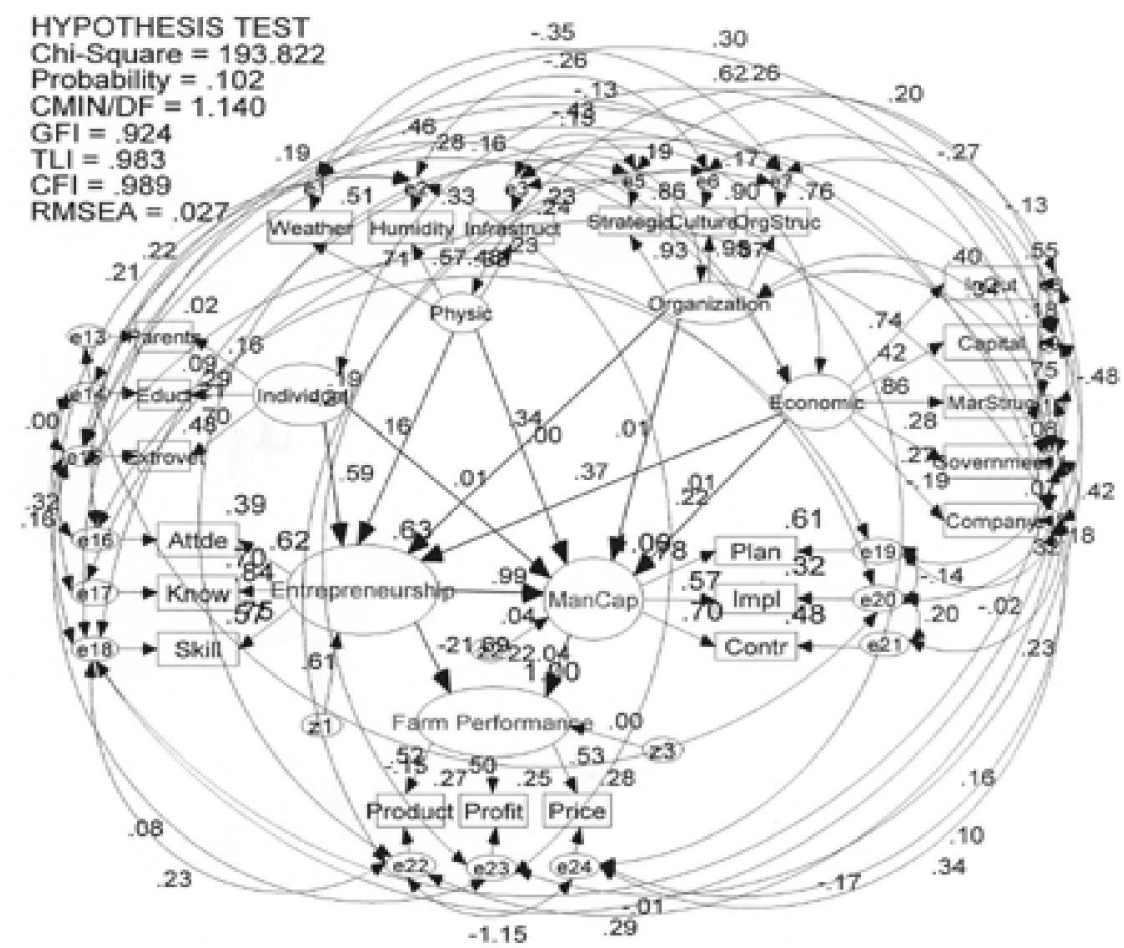

thus, convergent validity was established. The discriminant validity was established by determining that the average variance extracted by each latent variable's measure was larger than its shared variance with any other latent variables. The overall fit was acceptable $($ Chi-square $=209.712, \mathrm{p}<$ 0.086 ; GFI $=0.917$, AGFI $=0.874$, $\mathrm{RMSEA}=0.027, \mathrm{CMIND} / \mathrm{DF}=1.146$, $\mathrm{TLI}=0.981, \mathrm{CFI}=0.986$ ).

The common source bias was checked with a confirmatory factor analysis using the AMOS program by linking a common latent variable with the measures. The resultant lambda coefficient was more than 0.4 at $\mathrm{p}<$
0.05 , indicating that the common variance was less then 3 percent. This indicated that the solution of the model produced an acceptable fit.

The results of this research indicated that the multilevel model with physical, economic and organizational environments, as well as entrepreneurship-management capacity, could easily explain farm performance.

In this research, there were three levels of analysis: external environment, entrepreneurship and management capacity and concluding the direct or indirect impact, we can explore the complete comprehension model of farm performance. Moreover, from the 
Priyanto-AStructuralModelofBusinessPerformance

Figure 4. Result of Multilevel Analysis of Competing Model 2

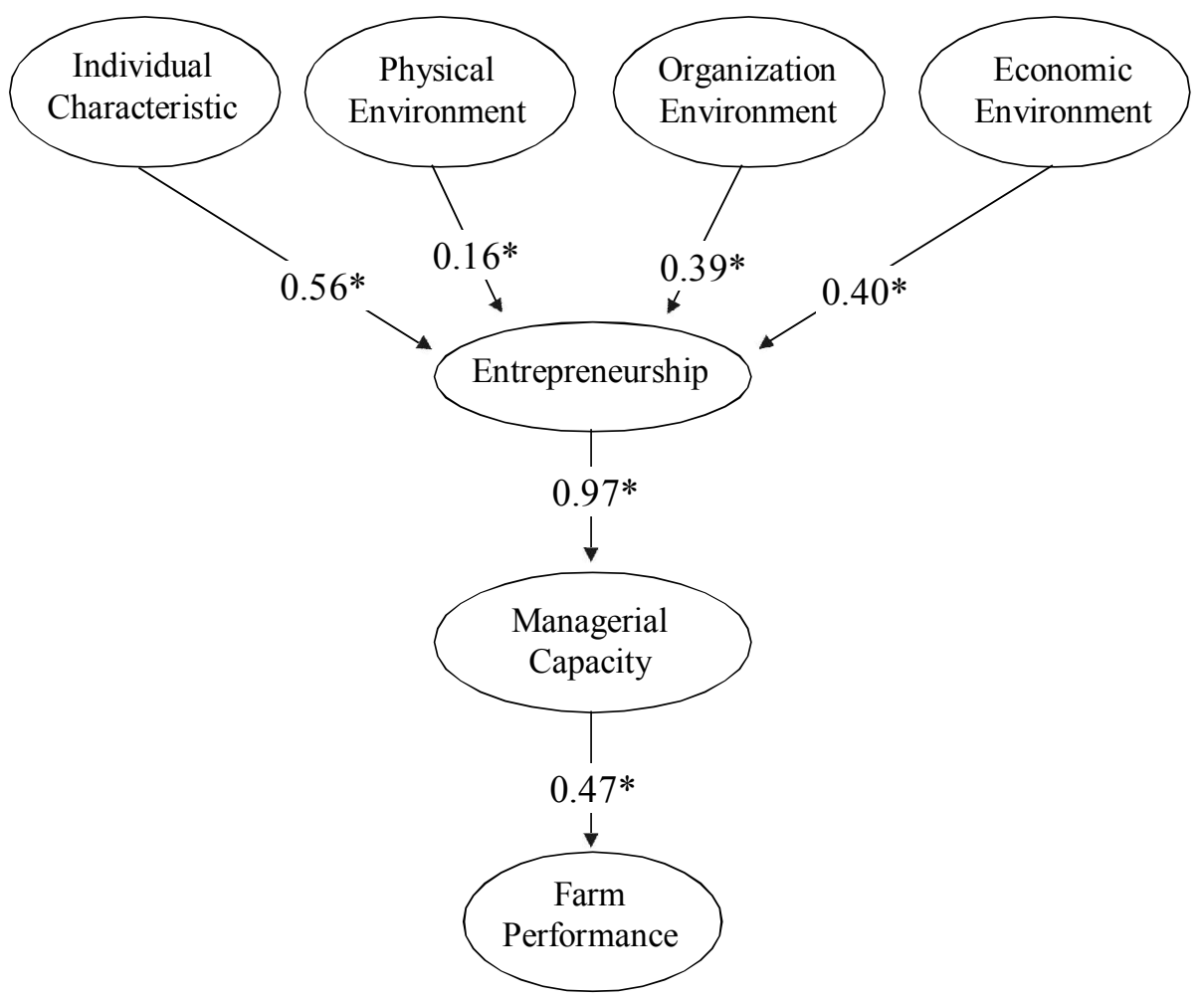

Table 3. SEM Analysis Result of Lambda Coefficiency of the Models

\begin{tabular}{|c|c|c|c|c|}
\hline & & $\begin{array}{c}\text { Proposed } \\
\text { Model }\end{array}$ & $\begin{array}{c}\text { Competing } \\
\text { Model } 1\end{array}$ & $\begin{array}{c}\text { Competing } \\
\text { Model } 2\end{array}$ \\
\hline EntPre & $\rightarrow$ EconEnv & $0.23 *$ & $0.37 *$ & $0.39 *$ \\
\hline EntPre & $\rightarrow$ OrgEnv & $0.35 *$ & $0.34 *$ & $0.39 *$ \\
\hline EntPre & $\rightarrow$ IndChar & $0.65 *$ & $0.59 *$ & $0.56 *$ \\
\hline EntPre & $\rightarrow$ PhysEnv & $0.23 *$ & $0.16 *$ & $0.16 *$ \\
\hline ManCap & $\rightarrow$ EntPre & $1.00 *$ & $0.99 *$ & $0.97 *$ \\
\hline Perform & $\rightarrow$ ManCap & $1.00 *$ & $-22.04 \mathrm{~ns}$ & $0.47 *$ \\
\hline Perform & $\rightarrow$ EntPRe & & $-21.69 \mathrm{~ns}$ & \\
\hline ManCap & $\rightarrow$ PhysEnv & & $0.00 \mathrm{~ns}$ & \\
\hline ManCap & $\rightarrow$ IndChar & & $0.01 \mathrm{~ns}$ & \\
\hline ManCap & $\rightarrow$ OrgEnv & & $0.01 \mathrm{~ns}$ & \\
\hline ManCap & $\rightarrow$ EconEnv & & $0.05 \mathrm{~ns}$ & \\
\hline
\end{tabular}


Gadjah Mada International Journal of Business, January-April2006, Vol.8, No. 1

Table 4. Overall Test Results

\begin{tabular}{|c|c|c|c|c|}
\hline Macro & & $\begin{array}{c}\text { Proposed } \\
\text { Model }\end{array}$ & $\begin{array}{c}\text { Competing } \\
\text { Model } 1\end{array}$ & $\begin{array}{c}\text { Competing } \\
\text { Model } 2\end{array}$ \\
\hline $\mathrm{X}_{2}$ & Chi-square & 971.791 & 193.822 & 209.712 \\
\hline $\mathrm{DF}$ & Degrees of freedom & 270 & 170 & 183.000 \\
\hline $\mathrm{P}$ & $\mathrm{P}$ & 0.000 & 0.102 & 0.086 \\
\hline CMINDF & Discrepancy / df & 3.599 & 1.14 & 1.146 \\
\hline GFI & GFI & 0.740 & 0.924 & 0.917 \\
\hline AGFI & Adjusted GFI & 0.688 & 0.876 & 0.874 \\
\hline TLI & Tucker-Lewis index & 0.636 & 0.983 & 0.981 \\
\hline CFI & Comparative fit index & 0.673 & 0.989 & 0.986 \\
\hline RMSEA & Root Mean Square & 0.115 & 0.027 & 0.027 \\
\hline
\end{tabular}

indirect model, it could be concluded that the explanation of individual factor (internal aspect) -that included the background, entrepreneurship aspect and management capacity- was more relevant to explain farm performance.

The explanation of the internal aspect of the farm performance indicates the importance of the entrepreneur's or farmer's role in strategy formulation and venture implementation. The characteristics the entrepreneur has are being a hard worker and proactive in the organization and the highest industry technicality. This highest ability is gained because of the concept and open attitude, broader networking, being educated to run his business, and supported by the parents' work culture. This kind of farmer is highly motivated and it is shown accurately on the organization observation with a high goal to achieve and the confidence to reach the goal (accurate in the organization observation, having a high goal to achieve and confidence to reach the goal). With regard to their capabilities and ability, the entrepreneur is also able to make an effective plan of differentiation strategy, to increase his product quality, to build a strong relationship by creating band belief. It can be concluded that the farmer's background, high motivation, risk taking characteristic, independence, creativity, and technical ability influence farm performance. This highly grown organization, the culture of organization is the reflection of the successful entrepreneur. The specific result was also investigated in order to elaborate further on the impact of the internal aspect on farm performance.

The Relationship between the External Factor and Entrepreneurship. The multilevel model reveals that the external factors affect farmers' entrepreneurship. These external factors are individual characteristics $(0.558)$, followed by economical environment 
Priyanto-AStructuralModelofBusinessPerformance

Table 5. Table of Standardized Total Effects - Estimates

\begin{tabular}{|c|c|c|c|c|c|c|c|}
\hline & PhysEnv & EconEnv & OrgEnv & IndChar & EntPre & ManCap & Perform \\
\hline EntPre & 0.162 & 0.392 & 0.385 & 0.558 & 0.000 & 0.000 & 0.000 \\
\hline ManCap & 0.156 & 0.378 & 0.371 & 0.539 & 0.965 & 0.000 & 0.000 \\
\hline Perform & 0.074 & 0.179 & 0.176 & 0.255 & 0.457 & 0.474 & 0.000 \\
\hline COMSUP & 0.000 & 0.225 & 0.000 & 0.000 & 0.000 & 0.000 & 0.000 \\
\hline PRICE & 0.039 & 0.094 & 0.092 & 0.134 & 0.240 & 0.249 & 0.526 \\
\hline PROFIT & 0.026 & 0.063 & 0.061 & 0.089 & 0.160 & 0.166 & 0.349 \\
\hline PRODT & 0.034 & 0.081 & 0.080 & 0.116 & 0.207 & 0.215 & 0.453 \\
\hline GOVPOL & 0.000 & 0.290 & 0.000 & 0.000 & 0.000 & 0.000 & 0.000 \\
\hline MARKSTRU & 0.000 & 0.882 & 0.000 & 0.000 & 0.000 & 0.000 & 0.000 \\
\hline CAPITAL & 0.000 & 0.432 & 0.000 & 0.000 & 0.000 & 0.000 & 0.000 \\
\hline IOPRICE & 0.000 & 0.730 & 0.000 & 0.000 & 0.000 & 0.000 & 0.000 \\
\hline ORGSTRUC & 0.000 & 0.000 & 0.875 & 0.000 & 0.000 & 0.000 & 0.000 \\
\hline BUSCULT & 0.000 & 0.000 & 0.953 & 0.000 & 0.000 & 0.000 & 0.000 \\
\hline BUSSTRA & 0.000 & 0.000 & 0.924 & 0.000 & 0.000 & 0.000 & 0.000 \\
\hline INFRSTRUC & 0.473 & 0.000 & 0.000 & 0.000 & 0.000 & 0.000 & 0.000 \\
\hline FERTL & 0.542 & 0.000 & 0.000 & 0.000 & 0.000 & 0.000 & 0.000 \\
\hline CLIMAT & 0.770 & 0.000 & 0.000 & 0.000 & 0.000 & 0.000 & 0.000 \\
\hline EDUCT & 0.000 & 0.000 & 0.000 & 0.296 & 0.000 & 0.000 & 0.000 \\
\hline PAREN & 0.000 & 0.000 & 0.000 & 0.216 & 0.000 & 0.000 & 0.000 \\
\hline EXTRVT & 0.000 & 0.000 & 0.000 & 0.678 & 0.000 & 0.000 & 0.000 \\
\hline CONTR & 0.114 & 0.277 & 0.272 & 0.395 & 0.707 & 0.732 & 0.000 \\
\hline IMPL & 0.096 & 0.231 & 0.227 & 0.329 & 0.590 & 0.612 & 0.000 \\
\hline PLAN & 0.126 & 0.304 & 0.299 & 0.434 & 0.776 & 0.805 & 0.000 \\
\hline ATTDE & 0.103 & 0.250 & 0.246 & 0.357 & 0.639 & 0.000 & 0.000 \\
\hline KNOW & 0.136 & 0.329 & 0.322 & 0.468 & 0.838 & 0.000 & 0.000 \\
\hline SKILL & 0.114 & 0.275 & 0.270 & 0.392 & 0.702 & 0.000 & 0.000 \\
\hline
\end{tabular}

(0.392), physical environment (0.162) and organizational environment (0.385) (see Figure 4 and Table 5). The result supports Lee and Tsang (2001) and other researchers like Begley and Boyd (1987) and Ducheneau and Gartner (1990), who stated that the venture success depends on the entrepreneur, rather than on other factors. Beets (1990) stated that exogenous circumstances influence the agriculture system and farm production. Similarly, Proshansky et al. (1970) stated that physical environment influences an individual's attitude in his social life, including his venture.

The individual characteristics that influencefarmers' entrepreneurship are determined by three factors: the farmer's psychological aspect (extroversion), his educational level, and his parents' work. The psychological aspect has the biggest influence on building someone's character to react to his or her business environment. An extrovert entrepreneur is expected to have 
Gadjah Mada International Journal of Business, January-April 2006, Vol.8, No. 1

more frequent communications with his business contacts, and to have a larger number of contacts or greater breadth of communication. Lee and Tsang (2001) stated larger networking will be beneficial to farmers because through the network, they will be able to get more business information that will be helpful in their business. They acknowledge that not only does a successful entrepreneur need to manage the internal operation of his firm, but he also needs to establish an external network.

The educational aspect also influences the farmer's characteristic. High education allows one to have a high stock of knowledge and experiences that differ from those with low education. The high stock of knowledge enables them to create their own environment and its resources. The higher the education level one has, themore knowledge he has, and the more easily he activate his venture innovation. To be able to develop one's venture well, one's educational level should be appropriate for his business sector (Hisrich and Peters 1992). However, it should be noted that there is not always a linear relationship between one's educational level and his ability because one's ability also depends on the learning process that takes place in the school.

Although there have been colorful stories of school drop-outs becoming highly successful entrepreneurs, the increasing complexity of business environment worldwide seems to indicate that education is an essential entrepreneurial quality. A positive relation be- tween educational levels and venture growth has been observed in a large manufacture. Cooper and Dunkelberg (1987) and Thompson (1986) found that in their Canadian and US samples, entrepreneurs had a significantly higher level of education than the general population. Similarly, Robinson and Sexton (1994), found that entrepreneurs had a higher level of education than those in the waged and salaried sector. They also found that there were positive relationships between the level of education and earning from self-employment.

In terms of occupation of entrepreneurs' parent, there is strong evidence that entrepreneurs tend to have selfemployed or entrepreneurial fathers. Parents' activity is also a factor that builds entrepreneurship. Having a father who is self employed provides a strong inspiration for the entrepreneur. The independent nature and flexibility of self employment exemplified by the father is ingrained at an early age. The overall parental relationship, whether entrepreneur or not, is perhaps the most important aspect of the childhood family environment in establishing the desirability of entrepreneur activity for the individual. Parents can be supportive and encourage their children to be independent, achievement and responsibility (Hisrich and Peters 1992).

Next, a factor analysis to find a factor that developed an economic environment was conducted, and the analysis reveals that the domain factor that builds an economic environment is the market structure $(0.75)$, followed by the price of input to output condition 
(0.88), capital access $(0.31)$, government policy (0.22) and support from cigarette manufacturers $(0.22)$.

The economic environment, in which the farmers live and run their business, influences entrepreneurship. Theratio of the input to the output price influences the farmers' motivation (need for achievement). If the ratio of the input to the output price is better (the output price is higher than the input price), the farmers will be motivated to run/improve their tobacco business. For example, the respondents in Klaten Regency has a better ratio of the input to output price than those of others. Their entrepreneurship condition gives good capital for them. It also influences the farmers' entrepreneurship. An easier way to get a capital for the farmer will motivate in their venture. It will increase their independence in selling their products (being able to get capital easily motivates the farmer to work harder in their venture and increases their independence in selling their products). As a result, this autonomy increases the farmers' bargaining position in facing the cigarette manufacturer. According to Mazzarol et al. (1999), economic factors, like capital availability, is supported by institutions (Bank, Local and Central Government), and regulations (such as bank credit interest subsidy); an access to capital information are of particular importance. The assets availability will influence the intentionality and decision making in running their business.
Farmers' accessibility to the costumer (in this case, traders and cigarette manufactures) also increases their attitude in venture. They will be brave to take a risk and increase their product quality, because they have known the market and dominated it. Tobacco farmers on the loan and contract systems are more enthusiastic in venture than farmers that have a free market system. Mazzarol et al. (1999), also showed that an entrepreneur who first gets the information will be more successful than others who get the information later on from the third person.

Tobacco market structures also influence farmers' entrepreneurship. Tobacco market structures dominated by some buyers (cigarette manufacturers) cause difficulties for the farmers. As a result, they become reluctant to speculate (take a risk). In this condition, the farmers' courage to plant according to the nature system, because of the order of the cigarette manufacturer, is difficult to know. In this situation, the farmers usually take the position to keep the relationship with the traders as the second hand cigarette manufacturers to make sure that their products are sold. Drucker (1985) stated that a regency's demography structure could increase an entrepreneur's innovation and creativity to fulfill thenecessities of the people.

In this monopsony market, other supporters, such as local and central government, association of tobacco farmers and cigarette manufacturers themselves will influence the need for 
Gadjah Mada International Journal of Business, January-April 2006, Vol.8, No. 1

achievement, risk, increasing creativity and expanding farmers' knowledge. Mazzarol et al. (1999) stated that the political situations, other supporters and regulations will influence the intentionality and the decision in doing business activities. Cigarette manufacturers' support that is expected by the farmers is about the price and their buying the products.

A factor analysis shows the factors which build the physical environment. These factors are weather (that consists of rainfall, temperature, and humidity), soil fertility (such as soil fertility structure, irrigation, and water available for the plants), technology development (such as cultivation technology and information technology), and the condition of the facilities (such as the streets, bridges, and transportation). The weather factor is the main factor that builds the physical environment. The physical environment also contributes to farmers' entrepreneurship. Soil fertility, weather, the availability of technology in the tobacco farm operation and the good condition of the facilities to do the operation really influence the need for achievement, risk taking behavior, autonomy, and farmers' creativity.

Soil fertility, sufficient water, production facilities necessary for the operation of the ventures can be found in Klaten Regency. The farmers' entrepreneurship there is also the highest compared to that in other areas, especially in Grobogan Regency. This lends support to what stated that fertile physical environment with access to water, capital, and economic information will motivate the people to study the use the resources which, in turn, will influence their abilities and capabilities. This is in line with what Watson and Scott (1998) proposed, i.e., resources and management factors, employees' condition, and technology will influence someone's entrepreneurship. A study conducted by Priyanto et al. (2002) showed that there is a different type of motivation between the area with good water sources and the area with poor water sources. Meanwhile, according to Beets, fertile physical environment makes farmers foresighted people. On the other hand, failures which farmers in wiped out area (such as in Grobogan Regency) have to suffer from put the farmers in a fatalistic situation - the situation in which the farmers do not have motivation, are not confident with the environment, and are reluctant to adopt new technology, because they are afraid to fail again. They passively depend on the environment condition and have difficulties to grow because they do not want to develop themselves. In relation to this, Beets (1990) stated that fatalism -an attitude of laisser fairebelieves that whatever happens is inevitable, often forms a major constrain on development. It happens because there are a lot of obstacles in doing the development or venture operation. They are reluctant to conserve their resources because they do not believe that it will be beneficial to them and their families. 
A factor analysis shows that the variables built into organizational environment are farmers' business strategy, farmers' business culture, farmers' organizational structures, and their association. From this research, it can be seen that organizational environment has a positive influence on the farmers' entrepreneurial activity. This supports whatBaumetal. (2001) stated, i.e., farmers' environment affects organizations. They also say that environmental stability is positively related to venture growth.

The organizations of tobacco farmers that build into farmers' entrepreneurship are farmer groups and tobacco farmers' association. The role of the organizations is usually to encourage the farmers to improve the tobacco cultivation techniques, provide agriculture facilities, and strengthen their bargaining position with the cigarette manufacturers. But not all farmers are active in the organization. They prefer doing their venture by themselves. The effort of farmers' organizations to expand the market is futile.

Business culture also influences farmers' entrepreneurship. Some farmer groups such as those in Temanggung and Kendal regencies have strong business culture in managing the tobacco farms' operation. Generally, they increase the productivity rate and help the venture to become efficient and progressive, but their organizations play a small role, because they do not have emotional relationships with the farmers. Their organizational structure is also less flexible to face the rapid change in the business environment.

The Relationship between Entrepreneurship and Management Capacity. Farmers' entrepreneurship is positively related with their management capacity. If they have a high level of entrepreneurship, they will be able to make a strategic plan, implement their plan into a venture activity, and evaluate their business. The SEM analysis shows that lambda coefficient of relationship between entrepreneurship and management capacity is 0.97 . It means the entrepreneurship variable is strongly related to the management capacity variable.

Some important aspects of management capacity are farmers' personal characteristics and skills. These can be divided into drives and motivation, abilities and personalities. It has often been assumed that farmers' personal characteristics and skills can explain differences in the success of the farm. Rougoor et al. (1998) maintained that these strong personal aspects, i.e., drive and motivation, capability, credibility and good biography, are the characteristics of successful business leaders who also dominate the business management aspect.

Biography backgrounds, ability, business skills, drive, and strong motivation have been shown to determine business planning, implementation, and control, which in turn, are related to the decision making process. This means that entrepreneurship influences management and how farmers make decisions in their businesses. 
Gadjah Mada International Journal of Business, January-April 2006, Vol.8, No. 1

In relation to this, Nuthall (2001) stated that decision makers are affected by emotions and stress. In line with this, Bohm and Pfister (1996) showed that emotions play an important role and can have a significant effect on the rationality of decisions. With regard to anxiety and decision, Matthew and Deary (1998) showed that neuroticism can affect decisions. Eysenck and Keane (1990) similarly noted that depressed people operate differently when in this state. Furthermore,
McGregor et al. (1995) found that British farmers did experience considerable stress. Thus, personality, emotions and current anxiety level must influence decision rationally and processes, and must be appropriately allowed for.

Glancey et al. (1998) proposed that an entrepreneur's characteristic will influence the managerial operation that will, in turn, influence the business performance. In other words, a person with a high level of entrepreneurship,

Table 6. Table of Standardized Direct Effects - Estimate

\begin{tabular}{|c|c|c|c|c|c|c|c|}
\hline & PhysEnv & EconEnv & OrgEnv & IndChar & EntPre & ManCap & Perform \\
\hline EntPre & 0.162 & 0.392 & 0.385 & 0.558 & 0.000 & 0.000 & 0.000 \\
\hline ManCap & 0.000 & 0.000 & 0.000 & 0.000 & 0.965 & 0.000 & 0.000 \\
\hline Perform & 0.000 & 0.000 & 0.000 & 0.000 & 0.000 & 0.474 & 0.000 \\
\hline COMSUP & 0.000 & 0.225 & 0.000 & 0.000 & 0.000 & 0.000 & 0.000 \\
\hline PRICE & 0.000 & 0.000 & 0.000 & 0.000 & 0.000 & 0.000 & 0.526 \\
\hline PROFIT & 0.000 & 0.000 & 0.000 & 0.000 & 0.000 & 0.000 & 0.349 \\
\hline PRODT & 0.000 & 0.000 & 0.000 & 0.000 & 0.000 & 0.000 & 0.453 \\
\hline GOVPOL & 0.000 & 0.290 & 0.000 & 0.000 & 0.000 & 0.000 & 0.000 \\
\hline MARKSTRU & 0.000 & 0.882 & 0.000 & 0.000 & 0.000 & 0.000 & 0.000 \\
\hline CAPITAL & 0.000 & 0.432 & 0.000 & 0.000 & 0.000 & 0.000 & 0.000 \\
\hline IOPRICE & 0.000 & 0.730 & 0.000 & 0.000 & 0.000 & 0.000 & 0.000 \\
\hline ORGSTRUC & 0.000 & 0.000 & 0.875 & 0.000 & 0.000 & 0.000 & 0.000 \\
\hline BUSCULT & 0.000 & 0.000 & 0.953 & 0.000 & 0.000 & 0.000 & 0.000 \\
\hline BUSSTRA & 0.000 & 0.000 & 0.924 & 0.000 & 0.000 & 0.000 & 0.000 \\
\hline INFRSTRUC & 0.473 & 0.000 & 0.000 & 0.000 & 0.000 & 0.000 & 0.000 \\
\hline FERTL & 0.542 & 0.000 & 0.000 & 0.000 & 0.000 & 0.000 & 0.000 \\
\hline CLIMAT & 0.770 & 0.000 & 0.000 & 0.000 & 0.000 & 0.000 & 0.000 \\
\hline EDUCT & 0.000 & 0.000 & 0.000 & 0.296 & 0.000 & 0.000 & 0.000 \\
\hline PAREN & 0.000 & 0.000 & 0.000 & 0.216 & 0.000 & 0.000 & 0.000 \\
\hline EXTRVT & 0.000 & 0.000 & 0.000 & 0.678 & 0.000 & 0.000 & 0.000 \\
\hline CONTR & 0.000 & 0.000 & 0.000 & 0.000 & 0.000 & 0.732 & 0.000 \\
\hline IMPL & 0.000 & 0.000 & 0.000 & 0.000 & 0.000 & 0.612 & 0.000 \\
\hline PLAN & 0.000 & 0.000 & 0.000 & 0.000 & 0.000 & 0.805 & 0.000 \\
\hline ATTDE & 0.000 & 0.000 & 0.000 & 0.000 & 0.639 & 0.000 & 0.000 \\
\hline KNOW & 0.000 & 0.000 & 0.000 & 0.000 & 0.838 & 0.000 & 0.000 \\
\hline SKILL & 0.000 & 0.000 & 0.000 & 0.000 & 0.702 & 0.000 & 0.000 \\
\hline
\end{tabular}

124 
as shown by his broad knowledge, strong characteristic and technical competency, finance and marketing, is surely able and skillful to make a strategic decision.

Direct effects of management capacity on performance. Management capacity is a factor that has a direct effect on farm performance. It positively influences about 0.474 or 47.4 percent (see Table 6). If the venture has a strategic plan, the venture's implementation of the plan is efficient and effective. Management capacity elements, such as planning, operating, and controlling of a venture, will increase the farm performance.

The role of tobacco farmers' groups or associations in planning, operating and controlling a venture is effective to increase farm production. Information about cultivation technology, including the technology to control or manage plant diseases, will help farmers to make their own decisions, so they are able to increase their productivity. In their study on the wheat farmers in England, Wilson et al. (2001) observed that the objectives of maximizing annual profit and maintaining the environment are positively correlated with, and have the largest influence on the farmers' technical efficiency. Moreover, farmers who seek information, have more years of managerial experience, and have large farms are also associated with higher levels of technical efficiency.

The farmers who are able to make a good plan for the market will get a fair price at the harvest time. Planning the right time to sell their products also becomes an important aspect to get a high price. The farmers' ability to maintain their business network is also determinant in setting up the price. Control by the tobacco farmers' association can increase the farmer's bargaining position. Therefore, they can get higher prices than the farmers who work on their own. Thus, the area with an active group of farmers and an association to strengthen the farmers can get a higher price for the products than other areas in which such groups or associations are nonexistent.

Farmers with good planning for planting, selecting the seed quality, plant treatment, and controlling the progress of the farm will produce a certain product quality (e.g., an $F$ quality). Their product usually can be sold at a high price -about $\mathrm{Rp} 60.000 / \mathrm{kg}$ because cigarette manufacturers are usually willing to buy an $F$ quality product ("srinthil") at a high price. This means that even though both the buyers and cigarette manufacturers determine the price, the farmers can indirectly determine the price too by determining the quality of their product in order to get a high price.

The effective and systematic planning and the consistency of venture implementation and control carried out by the farmers themselves or the associations are able to decrease the risk of failure and unnecessary costs. Moreover, they will increase the quality of the product. As a result, the price and the profit will increase, too. According to Gallacher et al. (1994), manage- 
ment, ownership, and monitoring have a greater impact on marketing efficiency -either technical or cost efficiency. Monitoring by others (for example by the association) can increase the marginal revenue.

In tobacco farm operation, benefit or loss depends on the productivity and the price that can be reached by the farmers. Both of them are important to determine the profit in tobacco business. The factor with the highest contribution to farm performance is the price $(0.526$ or $52.60 \%)$, followed by the production factor $(0.453$ or $45.3 \%)$ and profit $(0.349$ or $34.90 \%)$.

Indirect Effects of External Environment on Performance. The indirect effect of the external variable is low or not dominant, even though it is significant statistically. Themost dominant is individual characteristics, no matter how good the physical, economic, or organizational environment, because all of them depend on the role of individual characteristics. It is in line with Lee and Tsang (2001) who suggested that the individual factor is the most dominant factor to determine venture growth; others are just supporting factors to reach the best result.

Areas with a high fertility level (Klaten and Kendal), areas with supporting weather (Temanggung and Klaten), areas with sufficient facilities (Klaten), and areas with better technology access indirectly influence the profit. The fourth regency that was observed shows that the physical condition and the variety in the economic and organizational environment, cause variation in profit, prices, and production. Besides the entrepreneurship aspect and management capacity, the external aspects also play an important role in increasing farm performance.

Nuthall (2001) and Beets (1990) stated that venture performance is established by managerial ability of the farmer with other factors, such as goal identification, resources availability, agriculture environment and the regulations. All these factors also influence venture performance or growth.

In a market structure dominated by the customers (cigarette manufacturers), selling by himself will make the farmer experience loss. In a hegemony condition of cigarette manufacture, farmers should be united, not only in production planning but also in marketing. The decrease in prices is often caused by a large supply of tobacco in the market. Meanwhile, the cigarette manufacturers limit their buying. In this situation, all the organizations or associations that help the farmers should determine the bargaining position of the farmer with regard to price.

The flexible, conducive, business culture, and high level of work of an organizational environment will produce high business performance. According to Porter (1980), the strategy can be figured out into three business activities: focus (limited area), low price, and differentiation. Focus strategy determines the competitive strategy for special target customer, product line segment or geographical marketing. The low price strategy involves facility construction on an efficient 
scale, aggressiveness in cutting and minimizing the cost on an organizational function scale, and aggressiveness in selling the product to the customers who are sensitive to price (Dess and Davis 1984). The differentiation strategy is designed to create and sell the innovative and high quality products or services on an industry scale (Porter 1980).

According to Porter, the three competitive strategies above function as an alternative approach that is related to the strength of the environment. The firm that fails to select one of the three strategies above will be trapped (Porter 1980: 42). Porter argues that the trapped firm would be poor of investment in low cost structure to compete on a price, to have differentiation on an industry scale, to fulfill the low cost and to focus on reaching the low price on limited market. Dess and Davis (1984) found the empirical relationship for this hypothesis. Based on the explanation above, Baum et al (2001) concluded that the competition of the firm strategy is related to the performance. Specifically, the firms that stress on focus, low cost, and differentiation strategies will experience the highest growth.

Moreover Baumet al(2001) stated that "munificence points out the environment supporter, such as the growth of an organization (Dess and Beard 1984). The high munificence enables the firms to relate with their competitors to get the resources from outside. Complexity represents concentration or dispersed organization on environ- ment (Aldrich and Wiedenmayer 1993). The complex environment due to too many firms or producers, results in the difficulties to unite them." The tobacco farmers also face this condition. They often fail to build a relationship among them, especially in their dealings with the cigarette manufacturers. They have a tendency to have a relationship with the cigarette manufacturers separately. As a result, their bargaining position is weak.

The results show that individual characteristics also influence farm performance indirectly. In many cases, whether a venture succeeds or fails depends on personal characteristics. People with strong characteristics, expanded networking, education, and experiences that are supported by the background of their parents are usually more successful than others. The result of an observation by Baumet al. (2001) showed that personal characteristics, such as passion for work, tenacity, and being proactive, specific competency and higher levels of entrepreneurial motivation and confidence, positively influence venture growth.

Entrepreneurship. The entrepreneurship variable has a significant indirect role in the farm performance $(0.457$ or $45.7 \%$ ) (see Table 7$)$. To increase their productivity and reach the high price, farmers should have supporting attitudes. For example, they should have high need of achievement, be willing to take a risk, be autonomous, make a lot of efforts, and be creative to create a venture alternative that is supported by expanded knowl- 
Gadjah Mada International Journal of Business, January-April 2006, Vol. 8, No. 1

Figure 5. Result of Multilevel Analysis of Competing Model 2

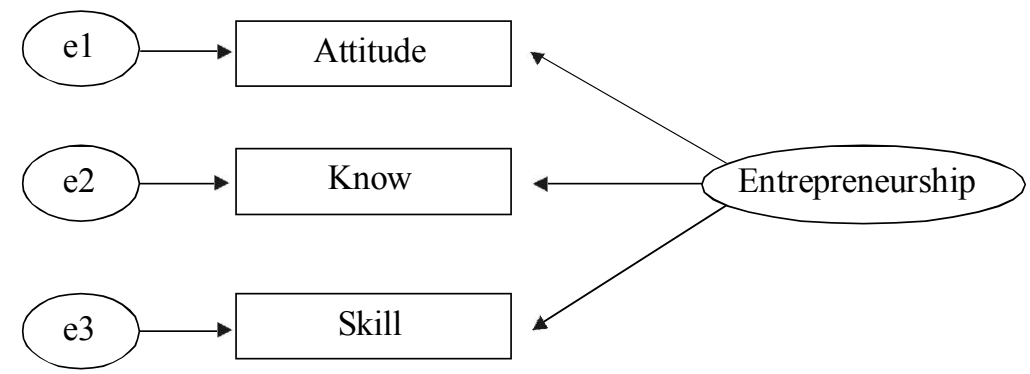

Table 7. Table of Standardized Indirect Effects - Estimates

\begin{tabular}{|c|c|c|c|c|c|c|c|}
\hline & PhysEnv & EconEnv & OrgEnv & IndChar & EntPre & ManCap & Perform \\
\hline EntPre & 0.000 & 0.000 & 0.000 & 0.000 & 0.000 & 0.000 & 0.000 \\
\hline ManCap & 0.156 & 0.378 & 0.371 & 0.539 & 0.000 & 0.000 & 0.000 \\
\hline Perform & 0.074 & 0.179 & 0.176 & 0.255 & 0.457 & 0.000 & 0.000 \\
\hline COMSUP & 0.000 & 0.000 & 0.000 & 0.000 & 0.000 & 0.000 & 0.000 \\
\hline PRICE & 0.039 & 0.094 & 0.092 & 0.134 & 0.240 & 0.249 & 0.000 \\
\hline PROFIT & 0.026 & 0.063 & 0.061 & 0.089 & 0.160 & 0.166 & 0.000 \\
\hline PRODT & 0.034 & 0.081 & 0.080 & 0.116 & 0.207 & 0.215 & 0.000 \\
\hline GOVPOL & 0.000 & 0.000 & 0.000 & 0.000 & 0.000 & 0.000 & 0.000 \\
\hline MARKSTRU & 0.000 & 0.000 & 0.000 & 0.000 & 0.000 & 0.000 & 0.000 \\
\hline CAPITAL & 0.000 & 0.000 & 0.000 & 0.000 & 0.000 & 0.000 & 0.000 \\
\hline IOPRICE & 0.000 & 0.000 & 0.000 & 0.000 & 0.000 & 0.000 & 0.000 \\
\hline ORGSTRUC & 0.000 & 0.000 & 0.000 & 0.000 & 0.000 & 0.000 & 0.000 \\
\hline BUSCULT & 0.000 & 0.000 & 0.000 & 0.000 & 0.000 & 0.000 & 0.000 \\
\hline BUSSTRA & 0.000 & 0.000 & 0.000 & 0.000 & 0.000 & 0.000 & 0.000 \\
\hline INFRSTRUC & 0.000 & 0.000 & 0.000 & 0.000 & 0.000 & 0.000 & 0.000 \\
\hline FERTL & 0.000 & 0.000 & 0.000 & 0.000 & 0.000 & 0.000 & 0.000 \\
\hline CLIMAT & 0.000 & 0.000 & 0.000 & 0.000 & 0.000 & 0.000 & 0.000 \\
\hline EDUCT & 0.000 & 0.000 & 0.000 & 0.000 & 0.000 & 0.000 & 0.000 \\
\hline PAREN & 0.000 & 0.000 & 0.000 & 0.000 & 0.000 & 0.000 & 0.000 \\
\hline EXTRVT & 0.000 & 0.000 & 0.000 & 0.000 & 0.000 & 0.000 & 0.000 \\
\hline CONTR & 0.114 & 0.277 & 0.272 & 0.395 & 0.707 & 0.000 & 0.000 \\
\hline IMPL & 0.096 & 0.231 & 0.227 & 0.329 & 0.590 & 0.000 & 0.000 \\
\hline PLAN & 0.126 & 0.304 & 0.299 & 0.434 & 0.776 & 0.000 & 0.000 \\
\hline ATTDE & 0.103 & 0.250 & 0.246 & 0.357 & 0.000 & 0.000 & 0.000 \\
\hline KNOW & 0.136 & 0.329 & 0.322 & 0.468 & 0.000 & 0.000 & 0.000 \\
\hline SKILL & 0.114 & 0.275 & 0.270 & 0.392 & 0.000 & 0.000 & 0.000 \\
\hline
\end{tabular}


Privanto-AStructuralModelofBusinessPerformance

edge of the venture, have abilities and skills to make use of tobacco cultivation techniques.

Entrepreneurship also can have direct influences on farm performance. Baum et al. (2001) stated that CEOs' specific competencies and motivations as well as firm competitive strategies were direct predictors of venture growth. CEOs' traits and general competencies and the environment had significant indirect effects on farm performance. Personal characteristics such as tenacity, being proactive, and passion for work; general competency such as organizational skill and ability to see opportunities; specific competency such as industrial skill and technical skill; a vision, growth or business goals, and self-efficacy as motivation concepts have demonstrated significant empirical relationships with business performance. It is consistent with the psychology theory that argues individual performances such as traits were important predictors of venture growth. (Hollenbeck and Whitener 1988, McClelland 1965). An entrepreneur's traits serve to influence the skill sets that are developed and the level of entrepreneurial motivation, which, in turn, affect strategy. It is the reason why practitioners and venture capitalists continue to point to the importance of the entrepreneur for venture success even though entrepreneurship trait research has not uncovered direct performance relations (MacMillan, et al. 1985).
Meanwhile, Lee and Tsang (2001) asserted that entrepreneurship elements such as experience, networking activities, number of partners and internal locus of control as well as the need for achievement all have positive impacts on venture growth. Other personality traits, self-reliance, and extroversion have negative impacts on the number of partners and positive impacts on networking activities. The impact of education on venture growth, however, is moderated by firm sizes positive for larger firms and negative for smaller firms.

The need for achievement is, therefore, a personality trait that has a greatest impact on venture performance. The entrepreneur's risk taking becomes the indicator that will encourage venture. However, according to Lee and Tsang (2001), this variable has a lower impact than the others. The entrepreneur's industrial and managerial experience has the greatest effect on venture growth. The positive impacts of networking activities (frequency and breadth of external communication) on the growth confirm, to a certain extent, the importance of quanxi in Chinese business communities.

\section{Conclusions and Future Research Direction}

This study is intended to develop a structural model which shows causal relationships between environment 
Gadjah Mada International Journal of Business, January-April 2006, Vol.8, No. 1

factors such as economy, natural resources, institutions and organizations, individual background, entrepreneurship, management capacity, and farm performance.

The most important finding of this study is that external environment (such as economy, natural resources, organizational, and individual characteristics), entrepreneurship (knowledge, attitude, skill) and management capacity (planning, implementation, controlling) research domains predict business performance better than the web of complex indirect relationships among them. This model uses a multilevel mechanism to describe business performance. A multilevel model using environment factors - such as economy, natural resources, organizational, and individual characteristicsentrepreneurship and management capacity is the fit model to portray farmers' business performance.

This study is a significant improvement over previous studies in terms of analysis techniques. Almost all of the existing studies in the same stream use conventional multivariate techniques (multiple regression, factor analysis and cluster analysis) and have never used multilevel analysis with variables formation such as: external environment, entrepreneurship, management capacity, performance.

The empirical result indicates that factors, such as personal aspects, physical, economic and institutional environments, affect farmers' entrepreneurship. Personal aspects become the dominant factor that determines entrepre- neurship and farm performance. This study also shows that farmers' entrepreneurship affected their management capacity, and the farmers' management capacity influence farm performance.

This model has never been explored before. The strengths of this study are, first, it explains the performance variation throughout the multilevel model relationships among the external environment, entrepreneurship, management capacity and farm performance. Second, this study can describe the relationship between entrepreneurship and management capacity. These two factors cannot be separated. They both are variables that connect to each other.

The findings are consistent with Watson and Scott (1998), Proshansky (1970), Beets (1990) who have found that physical environment will influence individuals' attitude in their social life, including their venture. Similarly, the findings support Schumpeter (1934), Hisrich and Peter (1992), Watson and Scott (1998), Lee and Tsang(2001) that stated individualcharacteristics such as psychological (extroversion), demographic and sociological aspects influence levels of entrepreneurship. The findings are also in line with what Watson and Scott (1998), Baumetal. (2001), Lambing and Kuelh (2000), Beets (1990) have found, i.e., organizational environment has positive influences on the entrepreneurial activity. Besides, the findings support Rougoors et al. (1998) and Nuthall (2001) who have found a significant 
relationship between management capacity and venture growth. Finally, the findings lend support to Rougoors et al. (1998) that stated the construct variables of management capacity are planning, implementing, and controlling.

Unfortunately, to explore the data, this research used perception data to measure external variables such as natural resources, economy, and institutional and social environments. It is suggested that future research can focus on a longitudinal observation that produces time series data.

For further study, this model can be validated in other fields, such as small and medium enterprises and other companies. This study does not include cross cultural and cross national social environment. To generalize the theory of business performance, therefore, this model can be tested in different contexts of cultures or nations with both cross sectional and longitudinal data.

\section{References}

Aldrich, H. E., and G. Wiedenmayer. 1993. From traits to Rates: An ecological perspective on organizational foundings. In J. A. Katz and R. H. Brockhaus, Sr. (Eds.): Advances in Entrepreneusrhip, Firm Emergence, and Growth 1: 145-195.

Beets, W. C. 1990. Raising and Sustaining Productivity of Smallholder Farming Systems in the Tropics. Holland: AgBe Publishing.

Bentler, P. M., and C. P. Chou. 1987. Practical Issues in Structural Modeling. Sociological Method and Research 16 (1): 78-117.

Blaikie, N. 2000. Designing Social Research. The Logic of Anticipation. Polity Press.

Blaum, J. R., E. A. Locke, and K. G. Smith. 2001. A multidimensional model of venture growth. Academic Management Journal 44 (2): 292-303.

Bohm, G., and H. Pfister. 1996. Instrumental or emotional evaluation: What determines preferences? Acta Psychol 93: 135-148.

Cantillon, R. 1755. Essai Sur la Nature du Commerce en Général. http:// socserv2.socsci.mcmaster.ca/ econ/ugcm/31l3/cantillon/essay1.txt

Cooper, A.C., and W. C. Dunkelberg. 1987. Entrepreneurial research: old questions, new answer and methodological issues. American Journal of Small Business 11 (3): 11-21.

Dess, G. G., and P. S. Davis. 1984. Porter's (1980) generic strategies as determinants of strategic group membership and organizational performance. Academy of Management Journal 27: 467-488.

Dess, G. G., and D. W. Beard. 1984. Dimention of organizational task environments. Administrative Science Quarterly 29: 52-73

Drucker, P. F. 1985). Innovation and Entrepreneurship: Practice and Principles. New York. 
Emory, C. W., and D. R Cooper. 1991. Bussines Research Methods (4 ${ }^{\text {th }}$. Ed). Richard D. Irwin, Inc.

Eysenck, M. E., and M. T. Keane. 1990. Cognitive Psychology - A Students' Handbook. London: Erlbanm Associates.

Ferdinand, A. 2002. Structural Equation Modelling dalam Penelitian Manajemen. Semarang, Indonesia: BP UNDIP.

Floyd, S. W., and B. Wooldridge. 1999. Knowledge creation and social network in corporate enterpreneuership: The renewal of organizational capability. Enterprenuership Theory and Practice 23 (3).

Foster, K. A., and A. Mwanaumo. 1995. Estimation of dynamic maize supply respon in Zambia. Agriculture Economics 12: 99-107.

Gallacher, M., S. J. Goetz, and D. L. Debertin. 1994. Managerial form, ownership and efficiency: A case study of Argentina agriculture. Agriculture Economics 11:289299.

Glancey, K., M. Greig, and M. Pettigrew. 1998. Entrepreneurial dynamics in small business service firms. International Journal Of Enterpreneurial Behaviour and Research 4 (3): 249-268.

Ghosh, B. C., T. W. Liang, T. T. Meng, and B. Chan. 1998. The key success factors, distinctive capabilities, and strategis thrusts of top SMEs in Singapore. Journal of Business Research 51: 209-221.

Grunert, K. G., A. Baadsgaard, H. H. Larsen, T. K. Madsen. 1996. Market Orientation in Food and Agriculture. Kluwer Academic Publishers.

Hisrich, R. D., and M. P. Peters. 1992. Entrepreneurship, Starting, Developing, and Managing a New Enterprise ( $2^{\text {nd }}$ ed.). USA: Irwin.

Hair J. R, R. E. Anderson, R. L. Tathan, and W. C. Black. 1995. Multivariate Data Analysis with Readings ( ${ }^{\text {th }}$ ed.). Prentice Hall Inc.

1998. Multivariate Data Analysis with Readings. (5 $5^{\text {th }}$ ed.). Prentice Hall Inc.

Hill, J., and P. McGowan. 1999. Small business and enterprise development: questions about research methodology. International Journal Of Enterpreneurial Behaviour and Research 5 (1): 5-18.

Hollenbeck, J., and E. Whitener. 1988. Reclaiming personality traits for personnel selection. Journal of Management 14: 81-91.

Hughes, M. A., R. L. Price, and D. W. Mars. 1986. Linking theory construction and theory testing: models with multiple indicators of latent variables. Academy of Management Review 11 (1): 128-144.

Kirk, D. 1998. Enterpreneurial context and behaviour in SMEs: An investigation of two contrasting manufacturing firms. International Journal OfEnterpreneurial Behaviour and Research 4 (2): 88-100.

Kohli, A. K., and B. J. Jaworski. 1990. Market orientation: The contruct, research propositions, and managerial implications. Journal of Marketing 54: 1-18. 
Priyanto-AStructuralModelofBusiness Performance

Lambing, P., and C. R. Kuehl. 2000. Enterpreneurship ( $2^{\text {nd }}$ ed.). New Jersey, USA: Prentice Hall, Inc.

Lee, D. Y., and E. W. K Tsang. 2001. The effect of entrepreneurial, background and network activities on venture growth. Journal Of Management Studies 38 (4): 583602.

Matthew, G., and I. J. Deary. 1998. Personality Trait. Cambridge: Cambridge University Press.

Mazzarol, T., T. Volery, N. Doss, and V. Thein. 1999. Factors influencing small business start-ups. International Journal of Enterpreneurial Behaviour and Research 5 (2): 48-63.

Mittal, K. C. 2003. Industrial Entrepreneurship. Deep and Deep Publications PVT. Ltd.

McClelland, D. C. 1961. Entrepreneur behavior and characteristics of entrepreneurs. The Achieving Society. Princeton: D. Van Nostrand.

McGregor, J., J. Willock, and I. Deary. 1995. Farmer stress. Farm Manage 9 (2): 57-65.

MacMillan, I. C, R. Siegel, and S. P. N. Narashima. 1985. Criteria used by venture capitalists to evaluate new performance. Journal of Business Venturing 5: 221-234.

Nuthall, P. L. 2001. Managerial ability-A review of its basis and potential improvement using psychological concepts. Agricultural Economic 24 247-262

Ohlmer, B., K. Olson, and B. Brehmer. 1998. Understanding farmers'decision processes and improving managerial assistance. Agriculture Economis 18: 273-290.

Okoroafo, S., and L. C. Russow. 1993. Impact of marketing strategy on performance: Empirical evidence from a liberalized developing country. International Marketing review 10 (1): 4-12.

Orser, B. J., S. Hogarth-Scott, and A. L. Riding. 2000. Performance, firm size and management problem solving. Journal of Small Business Management 38 (4) (October).

Porter, M. E. 1980. Competitive Strategy. New York: Free Press.

Proshansky, H. M., W. H. Ittelson, and L. G. Rivlin. 1970. Environmental Psychology: Man and His Physical Setting. Holt: Rinehart and Winstone, Inc.

Priyanto, S. H. 2002. Management capacity and entrepreneurship development in SME. Jurnal Ekonomi dan Bisnis Dian Ekonomi. III (3): 401-427.

Robinson, P. B., and E. A. Sexton. 1994. The effect of education and experience on selfemployment success. Journal of Business Venturing 9:P 141-156.

Rougoor, C. W., G. Trip, R. B. M Huirne, and J. A. Renhema. 1998. How to define and study farmers'manajemen capacity: Theory and use in agriculture economic. Agriculture Economis 18: 261-272.

Sadoulet, E., and A. de Janvry. 1995. Quantitative Development Policy Analysis. Baltimore and London: The Johns Hopkins University Press.

Schumpeter, J. A. 1961. In theory of Economic Development: an Inquiry into Profits, Capital, Credit, Interest, and The Business Cycle. New York: Oxford University Press. 
Gadjah Mada International Journal of Business, January-April 2006, Vol.8, No. 1

Sekaran, U. 2000. Research Method For Business ( ${ }^{\text {rd }}$ ed.). John Wiley and Sons, Inc.

Seyoum, E. T., G. E. Battese, and E. M. Fleming. 1998. Technical efficiency and productivity of maize producers in Eastern Ethiopia: a Study of Farmers within and Outside The Sasakawa-Global 2000 Project. Agriculture Economic 19: 341-348.

Shane, S. 2000. Prior knowledge and the discovery of entrepreneurial opportunities. Organization Science 11 (4): 448-469.

Skinner, and Ivancevich. 1992. Business for The 21 Century. USA: Richard D. Irwin, Inc.

Steel, R. G. D., and J. Torrie. 1989. Prinsip dan Prosedur Statistika Suatu Pendekatan Biometrik. Jakarta, Indonesia: PT. Gramedia.

Stevenson, H. H. 1983. A perspective on entrepreneurship Harvard business school. Working Paper 9: 384-131.

Stevenson, H. H., D. Gumpert. 1985. The heart of entrepreneurship. Harvard Business Review 63(2): 85-94.

Stevenson, H. H., and J. C. Jarillo. 1986. Preserving entrepreneurship as companies grow. Journal of Business Strategy 6: 10-23.

Stevenson, H. H., and J.C. Jarillo. 1990. A paradigm ofentrepreneurship: Enterpreneurical management. Strategic Management Journal 11 (Summer Special Issue):17-27.

Stoner, J. A. F. 1985. Management. New Delhi, India: Prentice Hall.

Thietart, R. A. (editor). 2001. Doing Management Research: A Comprehensive Guide. Sage Publication.

Thompson, P. 1986. Characteristics of small business entrepreneur in Canada. Journal of Small Business and Entrepreneurship 4 (1): 5-11.

Ward, P. T., R. Duray, G. K. Leong, and C. C. Sum. 1995. Business environment, operations strategy and performance: An empirical study of Singapore manufacturers. Journal of Operation management 13: 99-115.

Watson, K., and S. Hogarth-Scott. 1998. Small business start-ups: Success factors and support implications. International Journal of Enterpreneurial Behaviour and Research 4 (3): 217-238.

Wilson, P., D. Hadley, and C. Asby. 2001. The influence of magement characteristics on the technical efficiency of wheat farmers in Eastern England. Agriculture Economic 24: 329-338. 